Article

\title{
The Treaty Claims Settlement Process in New Zealand and Its Impact on Māori
}

\author{
Margaret Mutu \\ Faculty of Arts, University of Auckland, Auckland 1142, New Zealand; m.mutu@auckland.ac.nz
}

Received: 31 August 2019; Accepted: 14 October 2019; Published: 15 October 2019

\begin{abstract}
This article considers research conducted on the impact of the Crown's treaty claims settlement policy on Māori in New Zealand. It provides a brief background to the Treaty of Waitangi and the subsequent British colonisation process that relied on the Doctrine of Discovery in breach of the treaty. It outlines how colonisation dispossessed Māori of 95 percent of their lands and resources, usurped Māori power and authority and left them in a state of poverty, deprivation and marginalisation while procuring considerable wealth, prosperity and privilege for British settlers. The work of the Waitangi Tribunal, the commission of inquiry set up to investigate those breaches, is considered, as is the Crown's reaction to the 1987 Lands case in developing its treaty claims settlement policy. The Crown unilaterally imposed the policy despite vehement opposition from Māori. Since 1992, it has legislated more than seventy 'settlements'. The research shows that overall, the process has traumatised claimants, divided their communities, and returned on average less than one percent of their stolen lands. Proposals for constitutional transformation have drawn widespread support from Māori as a solution to British colonisation. United Nations treaty-monitoring bodies have recommended that the government discuss this with Māori.
\end{abstract}

Keywords: treaty claims settlements; Treaty of Waitangi; British colonisation; Doctrine of Discovery; Māori claimants; Crown policy; settler wealth and privilege; Māori deprivation and marginalisation; constitutional transformation; United Nations Declaration on the Rights of Indigenous Peoples

\section{Introduction}

In 2015, my colleague, Dr Tiopira McDowell, and I, along with seven research assistants and supporting kuia and kaumātua (elders) commenced a major research project on the impact that New Zealand's treaty claims settlement policy and process has had on Māori. The primary aim of the project was to address the absence of claimant voices in the discourse and literature on the policy and process. It also aimed to provide information desperately needed by those still trying to settle their treaty claims against the Crown. We examined government and ministerial documents to understand the purpose of the policy. We sought out the views and analyses of claimants recorded in formal submissions made to parliamentary select committees. We reviewed the reports of the Waitangi Tribunal and academic publications about the process. Yet, the interviews we conducted with more than 150 claimants and their negotiators provided the most detailed and reliable information about the nature and extent of the impacts the policy and process have had on Māori communities. Solutions are needed for the damage done by this policy as well as the ongoing devastation caused by British colonisation. We considered those that Māori identified in a major research project on constitutional transformation led by Dr Moana Jackson and the progress being made towards implementing the changes needed. Before providing details of the research and its findings, some background is required, firstly on the policy and its implementation and secondly on the broader context within which this policy sits. 


\subsection{The Treaty Claims Settlement Policy}

In December 1994, the New Zealand government released its unilaterally determined treaty claims settlement policy [1]. It drew immediate and vehement opposition from Māori, who unanimously rejected it [2-4] (pp. 13-27). In 1992, the government had secured a national settlement that extinguished all Māori rights and claims to their fisheries. The settlement had provided the government with a substantial windfall—legislation giving it exclusive ownership of multi-billion dollar Māori fisheries resources in exchange for a half share in a fisheries company, and a promise to give Māori twenty percent of any new fisheries quota that may be allocated in the future $[5,6]$. The government looked to replicate this multi-billion-dollar resource contribution by Māori to the Crown across all other treaty claims. In respect of lands, even though it had driven Māori off almost all their lands, the Crown still did not have clear title and needed to extinguish underlying Māori title. That had become urgent when Māori succeeded with the famous Lands case in the Court of Appeal in stopping the government privatising state-owned enterprise and crown forest lands without a legislative provision to protect Māori interests [7] (p. 367). The resulting legislation vested power in the Waitangi Tribunal to order the government to return land to Māori. The government's treaty claims settlement policy aimed to defeat this legislation. It would repeal the legislation on a settlement-by-settlement basis and impose a punitive regime on Māori claimants designed to assimilate them into the dominant white culture, and to entrench British colonisation and hence, the Doctrine of Discovery [8,9].

Before Māori could mount an alternative, the Crown drove through its first major land settlement with Waikato-Tainui in late 1995. The Crown had confiscated more than 1.2 million acres from Tainui in the 1860s and driven them into exile for twenty years. The settlement transferred $\$ 70$ million in cash and a tiny portion of their lands, a total package that the Crown valued at $\$ 170$ million. The Crown imposed the package despite having agreed that the lands confiscated were valued at more than $\$ 12$ billion. However, the package was not a full and final settlement. It left harbours, the Waikato river and certain lands to be negotiated later. Within Tainui, there were strong objections from some groups. Eventually, Tainui accepted the settlement reluctantly, pointing out that it was a Crown-determined offer made on a take-it-or-leave-it basis. There was no negotiation. Tainui were adamant that the settlement was not to set a precedent for other claims-it was too unfair and unjust [4] (pp. 25-26), [7,10]. The Crown ignored them and declared that Tainui's acceptance and then three years later, the largest South Island iwi (nation), Ngāi Tahu's acceptance, set the benchmark for all other treaty claims [7] (p. 367). The 1998 Ngāi Tahu settlement achieved an even greater windfall for the government. Ngāi Tahu's territories extended over almost all of the South Island, some 34.5 million acres. The 'quid pro quo' for Ngāi Tahu allowing their claims and legal rights to be extinguished was a package that the Crown valued at the same as Tainui's, $\$ 170$ million. Once again, it was Crown-determined and they recovered only a tiny portion of their lands [4] (pp. 73-74), [10].

Since 1998, more than sixty much smaller settlements have been legislated [11]. Each settlement extinguishes a number of claims, removing any legal rights claimants may have had to recover their lands and territories. Deeds of Settlement disingenuously describe these huge appropriations as acts of great magnanimity on the part of the iwi or hapu (grouping of extended families), falsely implying that they are willingly giving up almost all their lands and forgoing compensation "to contribute to the development of New Zealand" [12]. It is one of many myths the Crown has fabricated to justify its refusal to relinquish its claims to the lands, territories and resources of Māori. The 'quid pro quo' for these huge sacrifices is typically the take-it-or-leave-it offer for claimants to purchase back tiny areas of their own lands at full market price [7] (p. 367). The Crown simply refuses to give back what it stole. The Crown assigns a monetary value to some of the lands it is prepared to sell and gives claimants the choice of the land or the money or a combination. The assigned value amounts on average to the value of less than one percent of the land that was stolen [13]. The government pays no compensation for the widespread devastation it caused but rather uses the settlements to entrench the colonial structures and processes that caused it and continue to perpetuate it [9]. 


\subsection{The Broader Context}

Treaty claims settlements sit within the broader context that is underpinned by the agreements entered into by Māori and the British Crown in the 1800s. When Māori take claims against the Crown, they rely on the treaty entered into between Māori rangatira (leaders) and the British Crown in 1840, Te Tiriti o Waitangi (a borrowing into Māori of the phrase 'The Treaty of Waitangi'). The following background sections provide a brief background to the treaty and the subsequent British colonisation process that relied on the Doctrine of Discovery in breach of the treaty $[14,15]$. They outline how colonisation dispossessed Māori of 95 percent of their lands and resources, usurped Māori power and authority and left them in a state of poverty, deprivation and marginalisation while procuring considerable wealth, prosperity and privilege for British settlers $[16,17]$. The work of the Waitangi Tribunal, the commission of inquiry set up to investigate those breaches $[16,18]$ is outlined. The Crown's reaction to the Lands case in developing its treaty claims settlement policy [7] is also considered. Although governments made little progress initially, they have now legislated more than seventy 'settlements' with another thirty or so in preparation for legislation. The rest of this article discusses the research conducted into Māori experiences of the treaty claims settlement process along with possible solutions. Of these, the proposals for constitutional transformation have drawn widespread support from Māori and from some non-Māori, and recommendations from United Nations treaty bodies that the government discuss the matter with Māori and take steps to implement the United Nations Declaration on the Rights of Indigenous Peoples [19-22].

\section{Background, Methods and Databases}

\subsection{British Immigration}

European immigrants, mainly from Britain, began arriving in our territories seven generations ago. Initially, as our guests, they were afforded hospitality, support and protection. This included our rangatira giving them land to live on so that they would stay and contribute to the wellbeing of the community. Some of the British did reciprocate and the descendants of many of the early traders remain in those hapu to this day. Most did not. Rather than living under tikanga, that is, the law of the land, they chose instead to adopt the now outlawed European cultural Doctrine of Discovery $[15,23]$. This doctrine relies on the myth that white Christians are superior to all other peoples. It gives them permission to dispossess, enslave and exterminate other races, cultures and religions. Today, most Christian churches have repudiated the protestant edicts, typically Royal Proclamations, authorising these atrocities. However, the Catholic Church has not repudiated the papal bulls issued in 1493 to 'invade, capture, vanquish and subdue' indigenous peoples and ' ... to take away all their possessions and property' $[15,23,24]$. British colonised states, including New Zealand, continue to rely on the Doctrine [15]. Part of that myth involved portraying Indigenous Peoples as mindless savages in order to justify driving them out of their own lands.

The attitudes of supremacy held by British immigrants in the early 1800s posed problems for our rangatira. There were relatively few of them ${ }^{1}$ but many were unmanageable. Several rangatira undertook diplomatic missions to England and reached an agreement with the British rangatira, King George IV, to send an emissary to control his lawless subjects living in New Zealand [25] (p. 99). The British Resident and later a Governor were sent, but neither achieved their primary purpose of controlling the lawlessness of British immigrants.

1 In the early 1830s the European population in New Zealand was around 300. By 1840 it was approximately 2000 (Waitangi Tribunal 2014, p. 239) while the Māori population was at least several hundreds of thousands. 


\subsection{He Whakaputanga 1835}

In 1835, He Whakaputanga o te Rangatiratanga o Nu Tireni, which can be literally translated as A Declaration of the Sovereignty of New Zealand, was drafted and signed by rangatira throughout the north and from Waikato and Ngāti Kahungunu [25] (p. 166-167), [26] (pp. 17-18). It was a formal declaration of the sovereignty of the rangatira of the many hapu throughout the country. It declared that only the rangatira assembled at Waitangi could make laws to keep the peace and that they would never give law-making powers to anyone else [25], [26] (p. 18). An interpretation in English of He Whakaputanga was sent to King William IV and was duly acknowledged [25]. Many hapū, especially in the north, still consider He Whakaputanga to be the founding constitutional document of New Zealand.

\subsection{Te Tiriti o Waitangi 1840}

The continued lawlessness of British immigrants led to a further agreement between the rangatira and the British Crown. By 1840, the rangatira decided that the British rangatira had to take responsibility for the British immigrants. On 6 February, they signed Te Tiriti o Waitangi, a treaty written in the Māori language that confirmed He Whakaputanga, preserving the tino rangatiratanga (absolute and paramount power and authority including sovereignty) of the rangatira, of the hapu and of the people. It devolved kāwanatanga (governance) over British immigrants to the Queen of England [14,23,27]. It also made English custom available for the benefit of all. It was a treaty of peace and friendship, one that promised what the rangatira had asked for: acknowledgement and respect for their absolute power and authority throughout their territories, while relieving them of responsibility for lawless British immigrants [14]. Te Tiriti is effectively a codicil or addendum to He Whakaputanga. It set out the agreed immigration laws for British immigrants. Hence, it is part of the founding constitutional document of New Zealand. He Whakaputanga and Te Tiriti have remained in place without change to this day.

\subsection{British Lawlessness and Crown Myths}

Māori took the promises made in these documents seriously, viewing He Whakaputanga and Te Tiriti as sacred covenants. We expected our British guests to do the same. The refusal of these immigrants to honour the undertakings of their leader became apparent immediately as their lawlessness persisted. Despite British assertions of the authority of the Queen of England, she was unable to stop the lawlessness of her subjects. Furthermore, a Crown representative produced a fraudulent document written in English, which asserted that the rangatira agreed to cede sovereignty to the Queen of England. They did not. No such discussion had taken place at Waitangi. The very notion that rangatira would agree to give their mana, their ultimate power and authority derived from the gods, to a stranger living on the other side of the world is not only bizarre, it is also both humanly and logically impossible [14]. Crown agents also claimed that it was the treaty signed at Waitangi. It was not. The rangatira at Waitangi did not sign it [28] (pp. 31-32). Yet these falsehoods became the myths that provided the foundational elements of the intricate web of lies and deception that British immigrants wove to justify their colonising mission to dispossess Māori [29]. The production of this fraudulent document was followed just months later by a proclamation issued by the Queen of England's governor declaring that they had taken over the country, relying on the myth that their whiteness and their Christianity allowed them to say so and because the Doctrine of Discovery authorised it [30] (pp. 107-108). The fact that such a senseless statement would hold no weight with Māori, if they even knew about it, appeared to have been lost on the British immigrants as they pursued their dreams of individual wealth, prosperity and material possession. It was not until 2014 when the Waitangi Tribunal issued its report on its inquiry into He Whakaputanga and Te Tiriti that the lie of the rangatira ceding sovereignty was officially exposed and the illegitimacy of the assumption of British possession of the country was confirmed for Māori. 
The Doctrine of Discovery emboldened British immigrants to hone their myth-making skills. Myths were needed at every turn to justify dispossessing Māori of their country, their livelihoods and their well-being and usurping their power and authority. For example, British immigrants established a parliament imbuing it with the myth that it is the centre of power for the entire country. The myth included that Māori and all their territories and resources belonged to the British Crown and therefore, British immigrants could take control of them. The myth extended to their courts and government institutions being able to determine how Māori lives and resources would be used to benefit British immigrants. None of these institutions were established in accordance with Te Tiriti. To this day, their parliament, their courts and all their government institutions have no legitimate basis.

With complete disregard for the damage and destruction they were causing, British immigrants relied on this and myriad other myths to take control of the entire country, including the lives, lands and all the resources of whānau (extended families), hapū and iwi. To cover up the violence, brutality and criminal nature of their activities, they passed laws giving themselves unfettered powers to 'rule by administrative fiat' [15] (p. 208), [28] (pp. 123-146), [31] (p. 104), [32]. They made no attempt to replace the only legitimate written constitution of the country, He Whakaputanga and Te Tiriti. They simply refused to recognise it. As a result, unlike most other countries, they do not have a single-document constitution to protect the fundamental rights of its citizens, no single set of basic values and rules that everyone knows and agrees to abide by for the well-being of all. Instead, they made up policies and laws that sanctioned the theft of lands, forests, fisheries, airways, waterways, seas, minerals, foreshores, seabed and estates and anything else they could commodify from whānau and hapū throughout the country [16]. Once British immigrants had secured the lands and either slaughtered or driven the hapū out, destroying homes, waka (canoes), wāhi tapu (sacred sites) and crops and raping, plundering, pillaging as they went [30,33-36], they denied how they had done it. The myth of their inherent superiority allowed them to forget what they had done. For more than 150 years, they attacked and persecuted Māori and any others who dared to remind them of the criminal atrocities they had committed. To this day Europeans deny the racism they use to keep Māori oppressed and in a state of poverty, deprivation, marginalisation and powerlessness, despite being warned repeatedly by United Nations treaty-monitoring bodies of the urgent need to address the problem [20-22]. This was and is British colonization - that very simple process of brutal dispossession in which states from Europe assumed the right to take over the lands, lives and power of Indigenous Peoples who had done them no harm [30] (p. 102).

While considerable attention is accorded the devastation suffered by Māori, particularly in the reports of the Waitangi Tribunal, there is relatively little discussion about the power and privilege Europeans gained from colonisation. Borell, Moewaka Barnes and McCreanor [17] (p. 26) capture it well:

The Pākehā [European] settlers who acquired the land and material resources taken from Māori have reaped individual, collective and intergenerational rewards from that procurement. The accumulated effects over generations have dramatically improved the economic, social and political wellbeing of current descendants, both materially and structurally. Pākehā worldviews and the institutionalisation of Pākehā cultural norms in our national, governmental and civic institutions have served to reaffirm and entrench models of mental and social wellbeing.

By comparison, there is extensive evidence of racial discrimination in all aspects of the social world for Māori and national statistics quantify its effects [37] (pp. 92-93). It ranges from discrimination in employment and housing, to the general disparaging of Maori language and culture in contemporary New Zealand society. Borell et al. commented that these act as everyday reminders to all New Zealanders of the second-class status of the Māori people and renew the view that the Māori people, language and culture are inferior. These current experiences of discrimination perpetuate the historic trauma of colonisation [17] (p. 26). 


\subsection{Waitangi Tribunal}

Māori leaders have always fought to stop British colonisation and to repair the damage it has done. For over 150 years, governments vilified those leaders, but each generation of leaders trained the next knowing that ultimately, the sacred covenants had to be honoured. In the 1970s, protests against the theft of Māori lands and a number of land repossessions started attracting media attention [38]. In 1975, the government responded by setting up a permanent commission of inquiry, the Waitangi Tribunal. Its function is to inquire into Crown breaches of the treaty, to report and to make recommendations to the Crown for removal of the prejudice. The government's primary intention was not to address the numerous breaches of the treaty but rather to take the protest off the streets and away from public and international view [18] (p. 9-10). Initially, Māori had little confidence that the Tribunal was anything other than just another tool of oppression. In 1980, a new chair of the Tribunal was appointed. He was Māori-the first Māori to become a judge, Edward Taihākurei Durie. Claims to the Tribunal started being upheld. Since then, Māori have taken more than 2800 claims to the Tribunal, seeking:

- return of stolen lands, waters, seas, fisheries, airways, minerals, foreshores, seabed and other resources;

- $\quad$ protection of the natural environment from desecration and unsustainable development

- restoration and recognition of our language and culture;

- equitable access to commercial opportunities and to government resources and services including education, health, housing, and social welfare;

- recognition and upholding of our mana and sovereignty [37] (p. 94).

Not only has the Tribunal unraveled carefully woven Crown myths, it has also made hundreds of recommendations about the actions governments have to take to remedy the damage and destruction [29]. This includes relinquishing stolen lands, territories and resources to their rightful owners. International human rights instruments and in particular, the United Nations Declaration on the Rights of Indigenous Peoples, require this. New Zealand signed up to the Declaration in 2010. Yet, implementing those recommendations would mean destroying the myths, so governments usually reject or ignore Tribunal recommendations [39] or threaten to reduce its powers or abolish it if it ever used its powers to make recommendations ordering the government to return lands [7] (p. 367), [8] (pp. 604-605), [40] (p. 7). This is a very serious breach of the rule of law, but there are no constitutional fetters on Parliament or the executive [32] to stop it.

\subsection{Remedying Colonial Devastation}

The powers the Tribunal has had since 1988 to order the government to return land to Māori were legal rights that Māori won in the famous Lands case, New Zealand Maori Council v Attorney-General 1987 [41]. In that case, the Court of Appeal directed the Crown to prepare safeguards to ensure that the transfer of lands was consistent with treaty principles ${ }^{2}[15]$ (p. 230). The Crown reached an out of court agreement with the Māori Council that empowered the Waitangi Tribunal to order that state-owned enterprise, Crown forest and certain other lands be returned to Māori, along with compensation for forests [7]. For the first time, Māori had legal rights to recover their lands. The Court of Appeal advised the parties that they could re-open the litigation "in case anything unforeseen should arise" [41] (p. 719).

2 The "principles" of the Treaty of Waitangi attempt to by-pass the original treaty. The 1975 Treaty of Waitangi Act, which established the Waitangi Tribunal, gives the Tribunal the impossible task of reconciling 'the Treaty in the Maori language' (the valid Treaty) and 'the Treaty in the English language' (the fraudulent document) and coming up with a set of 'principles' against which to make recommendations. As a Crown body the Tribunal (wrongly) assumed-without inquiring-that the Crown claim to sovereignty was legitimate. The 'principles' it arrived at were based on this with the result that all its recommendations fall well short of upholding hapū and iwi sovereignty. Once the Tribunal did inquire, it found that Māori had not ceded sovereignty (Waitangi Tribunal 2014). See also Mutu 2010; Mikaere 2011. 


\subsection{Clawing Back Māori Legal Rights}

In 1990, a newly appointed Minister in Charge of Treaty of Waitangi Negotiations, Douglas Graham, took strong exception to the implications of the Lands case and its accompanying legislation. Rather than Māori being able to get recommendations for the recovery of their lands that the government would ignore, they could now get recommendations that were binding on the government and once ordered, the land had to be returned to its rightful owners [7]. For Graham, this threatened the Crown's proclaimed right to dictate what Māori could or could not have [2] (p. 41). In his book Trick or Treaty?, he asserts "only the government can decide ... The courts cannot do this. Neither can Maori" [2] (p. 41). Rather than repealing the offending legislation, which would have reopened the Lands case, he set about removing the threat, demonstrating the powerlessness of courts in New Zealand to restrict Parliament's behaviour [15] (p. 246). Without consultation with Māori, he developed a policy that aimed to shut down claimants' access to the legal remedies available in the Tribunal. Rather, he would send them into direct negotiations with the government where claims would be restricted to the realm of politics. In that arena, with no statutory framework to protect Māori interests, Māori are powerless and are at the whim and mercy of European politicians dedicated to preserving power, wealth and privilege in the hands of Europeans $[8,9,42]$. Overall, Māori experiences of the policy and the process used to implement it have been traumatic and disastrous. The meagre offerings governments make as the quid pro quo for Māori giving up their legal and human rights have torn their communities asunder. To understand the nature and extent of the impacts of the policy on Māori, our research team drew on several databases.

\subsection{Methods and Databases}

\subsubsection{Government Documentation}

The research drew on both government and Māori databases. In order to understand the origins, nature and intentions of the treaty claims settlement policy and process, we sought out information relating to its development. Māori took no part in the development-it was delivered to them as a fait accompli. Interviews with claimants confirmed this. The only information we found was in ministerial writings about the policy and in Cabinet papers and memoranda that set out the government's intent. The government agency established to represent the Crown against Māori, the Office of Treaty Settlements, published selected Cabinet materials in Crown Proposals for the Settlement of Treaty of Waitangi Claims: Detailed Proposals. The information is vague and sketchy and lacks detail on how the policy is to be implemented. It is clear in its assertions that the Crown and not Māori will determine what each settlement will be [2] (p. 41); in other words, there will be no negotiation, yet there is no information on the methodology the Crown uses to determine each settlement. Interviews with claimants indicated that the Crown repeatedly refused to divulge its methodology. The minister's own written account, Trick or Treaty? [2] provides some context and interpretation for the database, as do a number of academic analyses [8-10,13,31,42-51]. We were unable to find any information about the methodology used.

\subsubsection{Māori Data and Methodologies}

This government database does not provide any information on the impact of the policy on Māori. Some information is available in the reports of the Waitangi Tribunal on their inquiries into the settlement policy and process and in the submissions that Māori made to the Justice and Law Reform Select Committee (for the Waikato-Tainui 1995 settlement only) and the Māori Affairs Select Committee. These all show extreme concern about the policy and the process. Select committee submissions up to July 2008 are available at Archives New Zealand in Wellington. Submissions made since then are available on the New Zealand Parliament website. These sources provide several thousand submissions made by Māori and non-Māori individuals, whānau, hapū, iwi, marae, organisations, corporations, local and central government agencies and non-governmental organisations over the 
past three decades [52]. Submissions to government committees and the Tribunal are provided within a non-Māori framework for a non-Māori process. Lawyers for claimants often draft them to meet the non-Māori requirements of the process. This can, but does not always, mask and filter the experiences of claimants and negotiators.

To address this shortcoming, we conducted interviews with more than 150 claimants and their negotiators. Interviews were semi-structured. Information about the research and the general interview questions were provided several weeks before the interviews took place after I had conducted preliminary discussions with each of the interviewees to ascertain whether they wished to participate. Many of the interviewees approached our team asking to participate after being referred by other interviewees or having heard about the research project. We interviewed everyone who asked to participate. Each interviewee had the opportunity to withdraw at any stage after agreeing to participate. Only one interviewee did.

The primary interview question was "What is your story about the settlement of your whānau, your hapu and/or your iwi's Tiriti o Waitangi claim(s)?" A series of follow up questions covered a number of topics. These included how the iwi's treaty claims settlement policy compared with that of the Crown, the role of the Waitangi Tribunal in their claims and settlement, the mandating process, the negotiations process, disruptions and divisions amongst claimants, hapu and iwi, legal options, beneficial and detrimental aspects of settlement, international indigenous rights considerations, and reconciliation between Māori and the Crown. The interviewees chose where the interviews were to be conducted. They chose a range of venues throughout the country: their homes, their marae, their iwi administration offices, their workplaces, cafes or restaurants, by phone. Many, including a number from elsewhere in the country, asked to come to my office at the University of Auckland. Six chose to write their accounts. Some chose to be interviewed alone. Others were accompanied by one or often more of their whānau, hapū or iwi. Some called hui (gatherings) so that as many as thirty people were present and took part in the interview. Interviews were conducted in English or in Māori, whichever the interviewee preferred, or a combination of both. All the interviews were recorded. They ranged in length from 45 minutes to five hours, averaging approximately two hours.

The interviews provide very detailed accounts of the experiences Māori have had of the treaty claims settlement process and the impacts it has had on them. The accounts were all told using the interviewees' own frameworks, their own approaches and their own representations. They provided many insights into and analyses of the process. These have been disseminated through reports to regional and national hui [9] and negotiators are reporting already that they are proving to be helpful for those still trying to settle their claims. Ethical requirements restrict access to the interviews database. Some interviewees participated on condition of anonymity, including several professionals and those still trying to negotiate settlements. They feared retribution from the Office of Treaty Settlements and/or the Minister that would have repercussions for their hapu and iwi and for their careers. For most, the edited transcriptions of their interviews are still undergoing the approval process required before they can be made available. It is expected that, subject to the approval of the interviewees, a large number of the interviews will eventually be published.

Māori have been searching for solutions to the devastation caused by colonisation for more than one and a half centuries. The treaty claims settlement process is not a solution-rather, it perpetuates colonisation. The need for fundamental constitutional transformation has been apparent to Māori ever since British immigrants set up their illegitimate power structures. Many hui have discussed this matter over the decades. In 2010, National Iwi Chairs Forum, a group of 72 chairpersons of nations throughout the country, established a group to carry out work on constitutional transformation. The terms of reference of the research group, Matike Mai Aotearoa-the Independent Constitutional Transformation Working Group-were

"To develop and implement a model for an inclusive Constitution for Aotearoa based on tikanga and kawa, He Whakaputanga o te Rangatiratanga o Niu Tireni of 1835, Te Tiriti o Waitangi of 
1840, and other indigenous human rights instruments which enjoy a wide degree of international recognition" [19] (p. 7).

The database developed for this project comprises recordings of 252 hui around the country, questionnaires completed at each hui, recordings of a further 70 hui conducted by rangatahi (youth) and a number of recorded interviews with experts. Ethical requirements restrict access to this database, although preliminary results were published in the report of Matike Mai Aotearoa in 2016.

As part of the solution, the United Nations Declaration on the Rights of Indigenous Peoples is an important internationally recognised human rights instrument. Its 46 articles are a blueprint for the implementation of Te Tiriti o Waitangi and can help New Zealand start out on its journey of constitutional transformation. Although New Zealand signed up to the Declaration in 2010, the government took no steps towards implementing it for several years. In 2014, National Iwi Chairs Forum established the Aotearoa Independent Monitoring Mechanism to formally monitor the government's progress towards implementing the Declaration. It includes several members of Matike Mai Aotearoa.

Since 2015, the Monitoring Mechanism has been compiling annual reports for National Iwi Chairs Forum and for the United Nations Expert Mechanism on the Rights of Indigenous Peoples, highlighting ongoing issues of concern to Māori. The reports draw together data from a number of sources, including court cases, government legislation, policy documents and reports and United Nations treaty-monitoring bodies' reports. These are all publicly available. The reports of the Monitoring Mechanism are available on the Expert Mechanism's website. The Monitoring Mechanism works closely with the New Zealand Human Rights Commission and compiles the reports in consultation with hapū and iwi around the country.

The 2015 report listed strategies that the government had reported to the United Nations and to United Nations treaty-monitoring bodies as demonstrating that it was complying with the Declaration. This report recommended a National Plan of Action to implement the Declaration. The 2016 report considered case studies in respect of the right to participate in decision-making matters which would affect Māori rights (Article 18): local government, the treaty claims settlement process, trade agreements and in particular, the Trans-Pacific Partnership Agreement. It also noted the completion and reporting on the five-year study on the need for constitutional transformation. The 2017 report noted that the government had started to engage with the Monitoring Mechanism and discussions had commenced developing a National Plan of Action. The Monitoring Mechanism identified the following priorities:

- An overarching priority of constitutional transformation

- Self-determination, underpinned by participation in decision-making and free, prior and informed consent (Articles 3-5, 18-20, 23, 32-35, 37, 45)

- $\quad$ Lands, territories and resources (Articles 10, 25-32)

- Cultural rights (Articles 8-13)

- Equality and non-discrimination (Articles 1, 2, 6, 7, 17, 21, 22, 44)

- Practical implementation of the Declaration and technical assistance (Articles 37, 39, 41, 42, 46).

Examples of areas within each of these priorities were identified as needing significant interventions in order to meet Declaration standards.

The 2018 report considered whether there had been progress on the 2017 priorities. It identified further areas where significant interventions are needed. It noted that the government was continuing to engage and that a Minister of Māori-Crown Relationships had been appointed. The 2019 report noted progress in engaging with the government to develop a National Plan of Action. The government agreed to a visit from Experts of the United Nations Expert Mechanism on the Rights of Indigenous Peoples to provide advice in that respect. The 2017 priorities were also reported on with further areas needing intervention identified. The government has not engaged with the overarching priority of constitutional transformation. 


\section{Findings, Outcomes and Recommended Solutions}

\subsection{The Government Treaty Claims Settlement Policy and Process}

A close reading of publications from the Office of Treaty Settlements detailing the development of the policy and then explaining the process highlights contradictions: the true intent driving the development of the policy was the removal of Māori legal rights and the extinguishment of Mãori claims. The published 'motivation and objectives', on the other hand, eschewed the true intent, focussing instead on restoration of relationship, restoring the honour of the Crown and removing the sense of grievance for Māori. The true intent can be summarised as

- To unpick the legal rights won by Māori in the Lands case;

- To extinguish all historical claims and remove Māori rights to make further claims;

- $\quad$ To preserve European control over Māori lives, lands and resources [8,9];

Successful implementation of such a punitive regime required restrictions on how direct negotiations were to be conducted. The Cabinet minutes and memoranda indicate the steps the Crown was prepared to take to ensure that the Crown maintained complete control over the process. These included that there is no statutory framework within which negotiations are conducted. This prevents Māori who enter the process from challenging it in the courts [42]. The Crown will sidestep individual claims lodged in the Tribunal and only negotiate settlements with large natural groupings of iwi but will extinguish all individual claims the Crown identifies within the iwi without necessarily negotiating or settling them. The Crown decides settlements, not Māori. The total expenditure on settlements is not to exceed $\$ 1$ billion over ten years, and once it does, the two iwi who first allowed their claims to be extinguished (Waikato-Tainui and Ngāi Tahu) would have their settlements topped up-but no-one else would, even though these two settlements were the benchmarks for all others. Lands administered by the Department of Conservation, which make up one third of the country's lands, are not generally available and public access and recreation is guaranteed if any of these lands are included in any settlement. Lands that the Crown has sold and continues to sell to individuals or companies are referred to as 'private' and are not available, and the Crown will continue to sell land regardless of whether negotiations are taking place for its return. Natural resources, including minerals, seas, water, airways, foreshore and seabed, flora and fauna, are not available. And the Doctrine of Discovery underpins and informs negotiations and settlements, not Te Tiriti o Waitangi [8,9,27,43-45].

The Cabinet papers and memoranda also show that if claimants remained in the Tribunal seeking binding recommendations, they would face lengthy and costly delays as the Crown fought to stop them recovering potentially large tracts of their lands along with compensation $[8,9]$. The few who have been able to persist with this route have been fighting through the Tribunal and the courts for more than 30 years for binding recommendations [27]. To date, no one has succeeded, although the Court of Appeal recently ordered the Tribunal to make binding recommendations for two sets of claimants [53]. This case was the result of the Tribunal refusing to make binding recommendations for the Mangatū Incorporation of Te Aitanga a Māhaki iwi of the east coast and for Ngāti Kahu iwi of the Far North. They both appealed the Tribunal's decisions successfully with the Court finding in both cases that the Tribunal's legislation required it to make binding recommendations. Both are continuing to seek binding recommendations from the Tribunal.

The Crown's 'motivation and objectives' stand in sharp contrast to and appear to contradict its true intent. They are couched in terms of moral, social, legal and political principles that seek to achieve positive, harmonious and peaceful race relations. They seek to acknowledge and resolve historical injustices. They seek to restore the honour of the Crown and to remove the sense of grievance felt by Māori. They seek to improve the social and economic status of Māori and to assure claimants and the New Zealand public that the settlements would be fair, full and final [1]. 


\subsection{Claimant Experiences of Direct Negotiations}

The interviews with claimants and negotiators back up and provide more detail and explanations of the views provided in both the Justice and Law Reform and the Māori Affairs Select Committees submissions. They provide unequivocal evidence that the Crown has achieved none of its published motivations and objectives while the requirements of the process imposed on Māori have been disastrous. Overall, the process has traumatised claimants, divided their communities, and delivered on average less than one percent of what was stolen. Claimants know that despite what settlement legislation may say, the settlements are not full, not fair and not final and that, like all previous settlements, they will be revisited [9].

While every hapu and iwi has its own story to tell of their experiences, common themes were apparent. These included the way that the Crown adopts divide-and-rule tactics and pursues them ruthlessly. Claimant negotiators report almost without exception that the divisions and conflict caused will take generations to repair and heal. The Crown requires negotiations to be conducted confidentially. This puts negotiators under enormous pressure from their own people who demand openness and honesty in all matters. Negotiators report that there is no negotiation, the Crown dictates [27] (p. 286), [45], [54] (pp. 51-3). Public servants and ministers frequently mislead claimants and misrepresent facts in order to entice claimants into negotiations and then push settlements through [9] (pp. 215-216). Deeds of settlement are lengthy, dense, legal documents that obscure numerous undisclosed conditions imposed by public servants, including the removal of rights. Public servants conducting the negotiations fully exploit the gross inequality between the Crown with its endless resources and the material poverty of claimants, often running claimants into the ground financially to facilitate the imposition of a 'settlement' [51]. Negotiators frequently report being bullied by public servants and Crown agents and many report having settled under duress. As a result, many do not accept Crown apologies as they are meaningless. The Crown refuses to recognise or uphold mana and tino rangatiratiratanga in negotiations or in settlements and refuses to discuss or negotiate the settlement of colonisation. Many report the Crown refusing to discuss Waitangi Tribunal reports upholding their claims. International standards New Zealand has agreed to, such as the United Nations Declaration on the Rights of Indigenous Peoples, are also banned from both negotiations and settlements [27] (pp. 190, 289-299), [47] (pp. 87-114).

\subsection{Solutions-Constitutional Transformation}

The research on constitutional transformation started out in each hui and interview by clarifying the terms of reference. The report noted that the task was not to investigate how the treaty could fit into the current Westminster constitutional system, nor how Māori representation might be adequately addressed in the existing parliamentary framework. Instead, the group was to seek advice on a different type of constitutionalism, that is, based on He Whakaputanga and Te Tiriti. An early result was that it is clear that the Westminster constitutional system as implemented since 1840 does not and cannot give effect to Te Tiriti o Waitangi [19] (p. 14).

\subsubsection{Key Features}

The key features of a future environment for Māori were identified as including that Māori are fully recognised and respected and that tikanga (Māori law), mātauranga Māori (Māori knowledge systems), He Whakaputanga and Te Tiriti are part of natural order of country. In this environment, hapu and iwi exercise their own mana and all peoples have a respected constitutional place. There is a constitution for good, just and participatory government for and by all people that is consistent with agreed values and benefits everyone. As a result, all New Zealanders prosper and celebrate our heritage and Māori contribute positively to the growing international activity around constitutional transformation for indigenous peoples [19] (p. 17). 


\subsubsection{The Nature of Constitutions}

People sought and experts provided simple and accessible clarification on the nature of constitutions. Constitutions are about making decisions. Government is the process people choose to regulate their affairs. A constitution is the code/set of rules to describe how government will function, who will make rules, how to abide by them and live together amicably.

Constitutions are based on the concept of power (the philosophy of constitutional authority and the values that underpin it) and the site of power (the institution or place where society decides power is exercised and the limits placed on it). A constitution is a cultural creation. Two examples are the Western concept and site of power, which is hierarchical, and the Māori concept of site and power. The Western concept of power is that sovereignty is the "most high and perpetual power over citizens". The western site of power is the "monarch in Parliament" with absolute authority and dominion over the land and the people. The Māori concept of power is that of mana, the absolute power and authority derived from the gods. The Māori site of power is the ariki (paramount leaders) or rangatira. Power is bestowed by the people to be exercised in a way that is tika (right, correct), makes decisions by consensus, cares for the people, keeps the people together and both the political independence and the whakapapa (genealogy)-based interdependence of hapu and iwi is secure [19] (pp. 31-35).

\subsubsection{The Constitutional Foundation}

The data and discussions confirmed that any constitution should have some kind of values or normative foundation. People identified some of that foundation in the ideas and ideals of tikanga, He Whakaputanga, and Te Tiriti. An increasing number of Māori have been participating in international indigenous affairs in recent decades and a number of indigenous human rights instruments were identified in several hui as precedents for a new constitution. They included the following declarations that are all framed within the right to self-determination:

- the Kari-Oca Declaration (1992) on inalienable rights to lands and territories, resources and waters;

- the Mātaatua Declaration (1993) on cultural and intellectual property rights;

- the United Nations Declaration of the Rights of Indigenous Peoples 2007 (adopted by New Zealand in 2010)

Other models of indigenous governance that could be possible exemplars are:

- The Sámi Parliament;

- The constitution of the Plurinational State of Bolivia;

- Native American Governments.

The Sámi Parliament or Samediggi was established in Norway in 1989. It has an elected plenary body of thirty-nine representatives and deals with political initiatives relevant to the Sámi people. Although it operates under some restrictions, in particular, general framework conditions for Sami culture are still largely determined and governed by Norwegian government authorities [55] (p. 35), it does give some institutional and constitutional form to the Sámi right to self-determination.

The constitution of the Plurinational State of Bolivia is underpinned by Indigenous values. The environment is of primary importance as is the relationship people have with it and with each other.

Native American Tribal Governments operate on many Native American reservations. They are confined by Federal law and often mimic Federal or State structures. But they are an institutional expression of the rangatiratanga of Native Americans and thus their constitutional right to govern themselves [19] (pp. 40-67).

\subsubsection{Constitutional Values}

A common thread in the data and all discussions was that any constitutional models had to be based on certain values. Those identified may be conceptualised under the following broad headings listed in the Matike Mai Aotearoa report (p. 69): 
- The value of tikanga - the need to relate to or incorporate the core ideals and the 'ought to be' of living in Aotearoa.

- The value of community-the need for a constitution to facilitate the fair representation and good relationships between all peoples.

- The value of belonging - the need for a constitution to foster sense of belonging for everyone in the community.

- The value of place - the need for a constitution to promote relationships with, and ensure protection of Papatūānuku (the Earth Mother).

- The value of balance-the need for a constitution to ensure respect for the authority of rangatiratanga and kāwanatanga within the different and the relational spheres of influence

- The value of conciliation - the need for a constitution to have underlying jurisdictional base and means of resolution to guarantee a conciliatory and consensual democracy [rather than an adversarial and majoritarian one]

- The value of structure-the need for a constitution to have structural conventions that promote basic democratic ideals of fair representation, openness and transparency.

Based on these findings, the report goes on to suggest a vision for constitutional transformation, providing six indicative constitutional models which will be outlined briefly in Section 4 below.

Māori support for constitutional transformation has been widespread. There is also significant non-Māori support. Members of Matike Mai Aotearoa have delivered many talks, seminars and lectures and given numerous media interviews on it throughout the country and are still answering calls to hold hui to discuss it three years after their report was released. The report is required reading for many university courses. Not unexpectedly, the report has drawn attacks from adherents to the outlawed White New Zealand policy as they continue to advocate for adherence to the Doctrine of Discovery and White Supremacy.

\subsection{First Steps towards Constitutional Transformation-Implementing the United Nations Declaration on the Rights of Indigenous Peoples}

The United Nations Declaration on the Rights of Indigenous Peoples is normative. It sets out internationally determined minimum human rights standards that states are required to adhere to. Its 46 articles spell out very specifically how New Zealand can start implementing He Whakaputanga and Te Tiriti as the first steps towards constitutional transformation. In order to determine what the starting point would be, the Aotearoa Independent Monitoring Mechanism compiled the reports outlined in Section 2.8.2 above on New Zealand's compliance with the Declaration.

For the government policies identified in the 2015 report, neither the government nor the Monitoring Mechanism could produce evidence that policies were delivering in accordance with the Declaration. For each of the specific case studies considered in the 2016 to 2019 reports, compliance rates were low or zero for all the articles monitored. These results were confirmed in the reports of United Nations human rights treaty-monitoring bodies that also identified New Zealand's lack of compliance with international standards in many areas with respect to Māori [20-22]. The 2015 report of the Monitoring Mechanism identified the need for a National Plan of Action to implement the Declaration. In 2019, the government formally agreed to start drafting a Plan and accepted the Advice Note provided by Experts from the United Nations Expert Mechanism on the Rights of Indigenous Peoples [56]. The note highlighted the importance of making progress on constitutional transformation [56] (p. 10).

\section{Discussion and Conclusions}

The findings indicate that there are serious problems with the government's treaty claims settlement policy and process. Claimants do not accept that the settlements legislated under the policy are full and final and they will be revisited. Many aspects of the process are perverse and 
the impact they have on Māori is a 'form of contortion' [31] (p. 105). The problems stem from the attitudes and behavior adopted by the Crown. They derive from the Doctrine of Discovery and while they may have been acceptable in European societies and cultures up until the mid-20th century, the establishment of the United Nations after the World War II and its 1948 Universal Declaration of Human Rights outlawed those attitudes and behaviours. Since then, New Zealand has ratified a number of international treaties relating to the protection of human rights and included those rights in domestic law. These include the International Covenant of Economic, Social and Cultural Rights, the International Covenant for Civil and Political Rights and the Convention for the Elimination of All Forms of Racial Discrimination [57]. In 2010, New Zealand adopted the Declaration on the Rights of Indigenous Peoples. The treaty claims settlement policy and process violates all these international agreements. To avoid any legal consequences, governments ensured that the policy has no statutory framework. The country also has no recognised single-document written constitution, leaving the government free to deny and remove Māori human and legal rights at their political whim. The result is that despite Māori making claims as Māori, governments permit only English cultural precepts that are incompatible and inappropriate for key steps in the process used to extinguish the claims, forcing claimants to work within a framework not of their making [31] (p. 105). This includes determining who holds the mandate to negotiate, the negotiations process, how deeds of settlement are written, how the claimant community ratifies the deed, how legislation for the settlement is written and how settlement assets are to be administered.

Despite government assertions that Māori are happy with settlements [58], the research shows conclusively that they are not. The basis of all claims is the negative impacts of British colonisation. Governments have all refused to discuss colonisation and its entrenchment in institutions throughout the country. They have also refused to acknowledge and recognise Māori sovereignty that encompasses ownership of all our natural resources. The chasm that exists between Māori and government expectations of settlements means that claimants do not accept government assertions that the settlements are full and final-especially when less than one percent of what was stolen is returned. The United Nations and the Waitangi Tribunal have both told governments that the policy is deeply flawed. They have repeatedly recommended that governments reach agreement with Māori over the policy rather than persisting with it and its ongoing human rights and treaty violations [9] (pp. 208-209). For those who have accepted settlements, it has been a pragmatic stance to accept, in the short term, the limited nature of Crown 'settlements' with the expectation that in the long term, broader change may still occur or be forced by iwi [49] (p. 169).

Treaty claims extinguishments and the inevitable fallout from them are a direct result of the ongoing application of the myths of the Doctrine of Discovery. Māori leaders have always been outspoken about their refusal to accept the resulting colonisation and its illegitimate power structures. When the government established the Waitangi Tribunal to divert attention away from Māori anger and protest, the evidence produced unraveled the carefully woven myths, including the lie that Māori had ceded sovereignty to the British Crown. Yet, still, the Crown refused to mend its ways and honour He Whakaputanga and Te Tiriti. When they confiscated the country's foreshores and seabed from Māori in 2004 in the face of Māori and significant non-Māori outrage, the chairpersons of thirty iwi established the National Iwi Chairs Forum. The Forum has since grown to 72 members. It picked up the call to revisit the country's constitutional arrangements that had been discussed in Māori gatherings for several decades. Matike Mai Aotearoa-the Independent Working Group on Constitutional Transformation-was established. Their 2016 report proposed six indicative constitutional models. The models follow on from the 2014 report of the Waitangi Tribunal into He Whakaputanga and Te Tiriti. They are based on tikanga and Te Tiriti and have a focus on improved relationships that reflect self-determination, partnership and equality. They provide for Māori to exercise their mana and tino rangatiratanga, including their sovereignty in a 'sphere of influence' where Māori make decisions for Māori in accordance with their laws (tikanga) and for the Crown/government to make decisions for its people in its own 'sphere of influence' in accordance with its laws. The two spheres are called 
the rangatiratanga sphere and the kāwanatanga sphere. A third relational sphere appears in several of the models. It is where Māori and the government engage and make joint decisions. The report recommends further dialogue over the next five years, to enable Māori to agree a model and instigate constitutional transformation. There has been widespread support for constitutional transformation among Māori and a significant number of non-Māori, including both Europeans and non-Europeans.

The first steps towards constitutional transformation started when the government adopted the United Nations Declaration on the Rights of Indigenous Peoples in 2010. It was slow to follow up on its undertaking. In 2014, National Iwi Chairs Forum established the Aotearoa Independent Monitoring Mechanism that works closely with the Human Rights Commission. Five years later the government agreed to work with the Monitoring Mechanism and the Human Rights Commission to draft a National Plan of Action to implement the Declaration. The Monitoring Mechanism's overarching priority is constitutional transformation. As poverty, deprivation and marginalisation continue to be the reality for most Māori, many defy a government they deem illegitimate and where they can, return to their cultural and ancestral roots to exercise their mana and tino rangatiratanga under the tikanga they inherited from their ancestors. Formal acknowledgement of this reality and the political will to restore the peace and balance that colonisation destroyed is long overdue.

Funding: This research was funded by the Royal Society of New Zealand-Te Apārangi Marsden Fund grant number UOA1426, the University of Auckland Performance Based Research Fund (Te Wānanga o Waipapa allocation), the JR McKenzie Trust, Ngā Pae o te Māramatanga-New Zealand's Māori Centre of Research Excellence and Te Puni Kōkiri.

Conflicts of Interest: The author declares no conflict of interest. The funders had no role in the design of the study; in the collection, analyses, or interpretation of data; in the writing of the manuscript, or in the decision to publish the results.

\section{References}

1. Office of Treaty Settlements. Crown Proposals for the Settlement of Treaty of Waitangi Claims-Detailed Proposals; Crown Proposals for the Settlement of Treaty of Waitangi Claims-Summary; Crown Proposals for the Settlement of Treaty of Waitangi Claims-Consultation with Māori; Office of Treaty Settlements: Wellington, New Zealand, 1994.

2. Graham, D. Trick or Treaty? Institute of Policy Studies: Wellington, New Zealand, 1997.

3. Gardiner, W. Return to Sender: What Really Happened at the Fiscal Envelope Hui; Reed: Auckland, New Zealand, 1996.

4. Mutu, M. The State of Māori Rights; Huia: Wellington, New Zealand, 2011.

5. Mahuika, M. Māori Fishing. In The State of the Māori Nation: Twenty-First-Century Issues in Aotearoa; Mulholland, M., Ed.; Huia: Wellington, New Zealand, 2006; pp. 237-245.

6. Mutu, M. Fisheries Settlement: The Sea I Never Gave. In Treaty of Waitangi Settlements; Hayward, J., Wheen, N., Eds.; Bridget Williams Books: Wellington, New Zealand, 2012; pp. 114-123.

7. Williams, D. Unique Treaty-Based Relationships Remain Elusive. In Waitangi Revisited: Perspectives on the Treaty of Waitangi, 2nd ed.; Belgrave, M., Kawharu, M., Williams, D., Eds.; Oxford University Press: Melbourne, Australia, 2005; pp. 366-387.

8. McDowell, T. Diverting the Sword of Damocles: Why did the Crown Choose to Settle Māori Historical Treaty Claims? Aust. J. Politics Hist. 2018, 64, 592-607. [CrossRef]

9. Mutu, M. Behind the Smoke and Mirrors of the Treaty of Waitangi Claims Settlement Process in New Zealand: No Prospect for Justice and Reconciliation for Māori without Constitutional Transformation. J. Glob. Ethics 2018, 14, 208-221. [CrossRef]

10. Fisher, M. Waikato-Tainui and Ngāi Tahu's Treaty-settlement Negotiations with the Crown. In Reconciliation, Representation and Indigeneity: 'Biculturalism' in Aotearoa New Zealand; Adds, P., Bonisch-Brednich, B., Hill, R.S., Whimp, G., Eds.; Universitätsverlag Winter: Heidelberg, Germany, 2016; pp. 111-126.

11. Te Arawhiti: The Office for Māori Crown Relations. Te Kāhui Whakatau (Treaty Settlements): Year-to-Date Progress Report 1 October 2018-31 March 2019; Te Arawhiti: Wellington, New Zealand, 2019. Available online: https://www.tpk.govt.nz/en/a-matou-mohiotanga/crownmaori-relations/the-section-8i-report (accessed on 30 July 2019). 
12. Treaty Settlement Documents. Available online: https://www.govt.nz/treaty-settlement-documents/(accessed on 30 July 2019).

13. Mutu, M. Recovering Fagin's Ill-gotten Gains: Settling Ngāti Kahu's Treaty of Waitangi Claims Against the Crown. In Waitangi Revisited: Perspectives on the Treaty of Waitangi; Belgrave, M., Kawharu, M., Williams, D., Eds.; Oxford University Press: Melbourne, Australia, 2005; pp. 187-209.

14. Mutu, M. Constitutional Intentions: The Treaty Text. In Weeping Waters; Mulholland, M., Tāwahi, V., Eds.; Huia: Wellington, New Zealand, 2010; pp. 13-40.

15. Miller, R.J.; Ruru, J.; Behrendt, L.; Lindberg, T. Discovering Indigenous Lands: The Doctrine of Discovery in the English Colonies; Oxford University Press: Oxford, UK, 2010.

16. Waitangi Tribunal Reports. Available online: https://waitangitribunal.govt.nz/publications-and-resources/ waitangi-tribunal-reports/ (accessed on 30 July 2019).

17. Borell, B.; Moewaka Barnes, H.; McCreanor, T. Conceptualising historical privilege: The flip side of historical trauma, a brief examination. AlterNative 2018, 14, 25-34. [CrossRef]

18. Oliver, W.H. Claims to the Waitangi Tribunal; Department of Justice: Wellington, New Zealand, 1991.

19. Matike Mai Aotearoa. He Whakaaro Here Whakaumu Mō Aotearoa: The Report of Matike Mai Aotearoa-The Independent Working Group on Constitutional Transformation; University of Auckland and National Iwi Chairs Forum: Auckland, New Zealand, 2016.

20. United Nations Committee on Economic, Social and Cultural Rights (UNCESCR). Concluding Observations on the Fourth Periodic Report of New Zealand; United Nations Human Rights Office of the High Commissioner: Geneva, Switzerland, 2018. Available online: http://tbinternet.ohchr.org/_layouts/treatybodyexternal/ Download.aspx?symbolno=E\%2fC.12\%2fNZL\%2fCO \%2f4\&Lang=en (accessed on 30 July 2019).

21. United Nations Committee on the Elimination of Racial Discrimination (UNCERD). Concluding Observations on the Combined Twenty-First and Twenty-Second Periodic Reports of New Zealand, CERD/C/NZL/C/21-22; United Nations Human Rights Council: Geneva, Switzerland, 2017. Available online: http:/tbinternet.ohchr.org/ _layouts/treatybodyexternal/Download.aspx?symbolno=CERD/C/NZL/CO/21-22\&Lang=En (accessed on 30 July 2019).

22. United Nations General Assembly (UNGA). Draft Report of the Working Group on the Universal Periodic Review: New Zealand, A/HRC/WG.6/32/L.1; United Nations General Assembly: New York, NY, USA, 2019. Available online: https://www.hrc.co.nz/files/1315/4984/7007/nzupr3-draftoutcome.pdf (accessed on 30 July 2019).

23. United Nations Economic and Social Council. Preliminary Study of the Impact on Indigenous Peoples of the International Legal Construct Known as the Doctrine of Discovery; United Nations Economic and Social Council: New York, NY, USA, 2010. Available online: https://www.un.org/esa/socdev/unpfii/documents/E.C.19.2010. 13\%20EN.pdf (accessed on 30 July 2019).

24. Get Religion. Available online: https://www.getreligion.org/getreligion/2018/1/22/doctrine-of-discovery-stillrelevant-when-covering-pope-francis-outreach-to-indigenous-tribes (accessed on 30 July 2019).

25. Waitangi Tribunal. He Whakaputanga me Te Tiriti: The Declaration and the Treaty: The Report on Stage 1 of the Paparahi o Te Raki Inquiry (Wai 1040); Legislation Direct: Wellington, New Zealand, 2014.

26. Mutu, M. The Humpty Dumpty Principle at work: The role of mistranslation in the British Settlement of Aotearoa. 'He Whakaputanga o te Rangatiratanga o Nu Tireni' and 'The Declaration of Independence'. In For Better or for Worse: Translation as a Tool for Change in the Pacific; Fenton, S., Ed.; St Jerome: Manchester, UK, 2004; pp. 11-36.

27. Mutu, M.; Pōpata, L.; Te Williams, K.; Herbert-Graves, A.; Rēnata, R.; Cooze, J.A.; Pineaha, Z.; Thomas, T.; Kingi-Waiaua, T.I. Ngāti Kahu: Portrait of a Sovereign Nation; Huia: Wellington, New Zealand, 2017.

28. Mikaere, A. Colonising Myths: Māori Realities; Huia: Wellington, Huia, 2011.

29. Mutu, M. Unravelling Colonial Weaving. In Stroppy Old Women; Little, P., Nissen, W., Eds.; Paul Little Books: Auckland, New Zealand, 2015; pp. 165-178.

30. Jackson, M. In the End "The Hope of Decolonisation". In Handbook of Indigenous Education; McKinley, E.A., Smith, L.T., Eds.; Springer Nature: Singapore, 2019. [CrossRef]

31. Te Aho, L. The "False Generosity" of Treaty Settlements: Innovation and Contortion. In International Indigenous Rights in Aotearoa New Zealand; Erueti, A., Ed.; Victoria University Press: Wellington, New Zealand, 2017; pp. 99-117.

32. Rishworth, P. Writing things unwritten: Common law in New Zealand's constitution. Int. J. Const. Law 2016, 14, 137-155. [CrossRef] 
33. Waitangi Tribunal. Taranaki Report: Kaupapa Tuatahi: Te Muru me te Raupatu (Wai 143); GP Publications: Wellington, New Zealand, 1996.

34. Waitangi Tribunal. Ngāti Awa Raupatu Report (Wai 46); Legislation Direct: Wellington, New Zealand, 1999.

35. Waitangi Tribunal. Te Raupatu o Tauranga Moana: Report on the Tauranga Moana Confiscation Claims (Wai 215); Legislation Direct: Wellington, New Zealand, 2004.

36. Waitangi Tribunal. Te Urewera Volume I (Wai 894); Legislation Direct: Wellington, New Zealand, 2017.

37. Mutu, M. Māori of New Zealand. In Native Nations: The Survival of Fourth World Peoples, 2nd ed.; Neely, S., Ed.; JCharlton Publishing: Vernon, BC, Canada, 2017; pp. 87-113.

38. Harris, A. Hīkoi: Forty Years of Māori Protest; Huia: Wellington, New Zealand, 2004.

39. Te Kāwanatanga o Aotearoa. The Section 8I Report: A Report on the Progress Made in the Implementation of Recommendations Made by the Waitangi Tribunal; New Zealand Government: Wellington, New Zealand, 2018. Available online: https:/www.tpk.govt.nz/en/a-matou-mohiotanga/crownmaori-relations/the-section-8ireport (accessed on 30 July 2019).

40. Hamer, P. A Quarter Century of the Waitangi Tribunal. In The Waitangi Tribunal: Te Roopu Whakamana $i$ Te Tiriti o Waitangi; Hayward, J., Wheen, N.R., Eds.; Bridget Williams Books: Wellington, New Zealand, 2004; pp. 3-14.

41. Court of Appeal. New Zealand Maori Council v Attorney-General. N. Z. Law Rep. 1987, 1, 641-719.

42. Vertongen, B. Legal Challenges to the Treaty Settlement Process. In Treaty of Waitangi Settlements; Wheen, N.R., Hayward, J., Eds.; Bridget Williams Books: Wellington, New Zealand, 2012; pp. 65-78.

43. Mikaere, A. Settlement of Treaty Claims: Full and Final, or Fatally Flawed? N. Z. Univ. Law Rev. 1997, 17, 425-455.

44. Boast, R. Negotiations for Reconciliation: How they can exacerbate division as well as promote reconciliation. In Reconciliation, Representation and Indigeneity: 'Biculturalism' in Aotearoa New Zealand; Adds, P., Bonisch-Brednich, B., Hill, R.S., Whimp, G., Eds.; Universitätsverlag Winter: Heidelberg, Germany, 2016; pp. 95-109.

45. Coxhead, C. Where are the Negotiations in the Direct Negotiations of Treaty Settlements? Waikato Law Rev. 2002, 10, 13-38.

46. Coyle, M. Transcending Colonialism? Power and the Resolution of Indigenous Treaty Claims in Canada and New Zealand. N. Z. Univ. Law Rev. 2011, 24, 596-620.

47. Jones, C. New Treaty New Tradition: Reconciling New Zealand and Māori Law; University of British Columbia Press: Vancouver, BC, Canada, 2016.

48. Joseph, R. Unsettling Treaty Settlements: Contemporary Māori Identity and Representation Challenges. In Treaty of Waitangi Settlements; Wheen, N.R., Haywood, J., Eds.; Bridget Williams Books: Wellington, New Zealand, 2012; pp. 151-165.

49. Bargh, M. Post Settlement World (So Far): Impacts for Māori. In Treaty of Waitangi Settlements; Wheen, N.R., Haywood, J., Eds.; Bridget Williams Books: Wellington, New Zealand; pp. 166-181.

50. Rumbles, W. Treaty of Waitangi Settlement Process: New Relationship or New Mask? Paper Presented at the Compr(om)ising Post/Colonialism Conference, Woollongong, Australia, 10-13 February 1999. Available online: http://lianz.waikato.ac.nz/PAPERS/wayne/wayne1.pdf (accessed on 30 July 2019).

51. Tuuta, D. Māori Experiences of the Direct Negotiations Process; Crown Forestry Rental Trust: Wellington, New Zealand, 2003.

52. McDowell, T. Screaming from the Shadows: Māori Views on the Treaty Claims Settlement Process. Te Pouhere Kōrero Māori Hist. Māori People 2016, 8, 26-47.

53. Court of Appeal. Attorney-General v Haronga. N. Z. Law Rep. 2017, 2, 394-420.

54. Office of Treaty Settlements. Healing the Past, Building a Future: A Guide to Treaty of Waitangi Claims and Negotiations with the Crown; Department of Justice: Wellington, New Zealand, 2002.

55. Henriksen, J.B. Sami Self-determination. Gáldu Čála J. Indig. Rights 2010, 7-46.

56. United Nations Office of the High Commissioner for Human Rights: The Expert Mechanism on the Rights of Indigenous Peoples (EMRIP). Country Engagement Mission (8-13 April 2019)-New Zealand 14 July 2019 Advisory Note; United Nations Office of the High Commissioner for Human Rights: Geneva, Switzerland, 2019. Available online: https://www.ohchr.org/Documents/Issues/IPeoples/EMRIP/Session12/ EMRIPAdvisroyNoteNZ2019.docx (accessed on 15 October 2019). 
57. Human Rights Commission. Available online: https://www.hrc.co.nz/international-reporting/ (accessed on 15 October 2019).

58. Finlayson, C. Treaty settlements working for the betterment of us. New Zealand Herald. 6 February 2014. Available online: http://www.nzherald.co.nz/politics/news/article.cfm?c_id=280\&objectid=11197283 (accessed on 30 July 2019). 